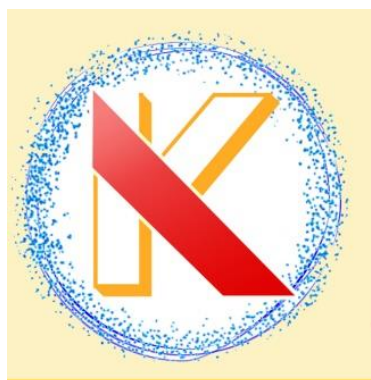

\title{
Penurunan Kadar Asam dalam Kopi Robusta (Coffea canephora) dari Desa Rantebua Kabupaten Toraja Utara dengan Teknik Pemanasan
}

\section{[Reduce Acid Levels in Robusta Coffee (Coffea canephora) from Rantebua Village, North Toraja District by Heating Techniques]}

\author{
Syahruddin Kasim ${ }^{1 *}$, Syarifuddin Liong ${ }^{1}$, Ruslan $^{2}$, Alprianto Lullung ${ }^{1}$ \\ ${ }^{1)}$ Departemen Kimia Fakultas Matematika dan IImu Pengetahuan Alam Universitas Hasanuddin, Makassar \\ 2) Jurusan Kimia Fakultas Matematika dan IImu Pengetahuan Alam Universitas Tadulako, Palu
}

*)Coresponding Author: kasimsyahruddin@gmail.com

\begin{abstract}
Robusta coffee (Coffea canephora) is the most widely produced coffee in Indonesia. The relatively high acid content causes robusta coffee to be less attractive to both local and international consumers. Acid levels in coffee can be reduced by heating techniques using water as a solvent because it is cheap and easy to obtain and water is also a safe solvent and has no side effects for health. Coffee bean water content was analyzed by heating to a constant weight by the oven method, acid content by titration technique and followed by organoleptic testing. The results of the analysis of water content for dry treatment of $10.02 \%$, wet treatment of $10.35 \%$, and on heating for $15,30,45,60,75$ and 90 minutes respectively at $9.99 \% ; 10.34 \% ; 9.70 \% ; 10.40 \%$; $11.65 \%$, and $11.36 \%$. The results of the analysis of acid levels for the treatment of dry processing amounted to $3.65 \%$, wet processing amounted to $3.42 \%$, and for heating for $15,30,45,60,75$ and 90 minutes respectively $3.03 \% ; 2.76 \% ; 2.51 \% ; 2.39 \% ; 2,32 \%$, and $2,28 \%$. Organoleptic test results showed that the decline in the quality of coffee occurs when heating above 45 minutes. Based on research data it was concluded that the heating method can reduce acid levels in coffee beans with a maximum heating time of 45 minutes to maintain the quality of taste in coffee.
\end{abstract}

Keywords: Coffea canephora, organoleptic, warming up, titration.

ABSTRAK. Kopi robusta (Coffea canephora) merupakan kopi yang paling banyak diproduksi di Indonesia. Kandungan asam yang relatif tinggi menyebabkan kopi robusta kurang diminati baik konsumen lokal maupun internasional. Kadar asam pada kopi dapat diturunkan dengan teknik pemanasan dengan menggunakan air sebagai pelarut karena murah dan mudah diperoleh serta air juga merupakan pelarut yang aman dan tidak memiliki efek samping bagi kesehatan. Kadar air biji kopi dianalisis dengan pemanasan sampai bobot konstan dengan metode oven, kadar asam dengan teknik titrasi dan dilanjutkan dengan uji organoleptik. Hasil analisis kadar air untuk perlakuan pengolahan kering sebesar 10,02\%, pengolahan basah sebesar $10,35 \%$ dan pada pemanasan selama 15, 30, 45, 60, 75 dan 90 menit berturut-turut sebesar 9,99\%; 10,34\%; 9,70\%; 10,40\%; $11,65 \%$ dan $11,36 \%$. Hasil analisis kadar asam untuk perlakuan pengolahan kering sebesar 3,65\%, pengolahan basah sebesar 3,42\%, dan pada pemanasan selama 15, 30, 45, 60, 75 dan 90 menit berturut-turut sebesar $3,03 \% ; 2,76 \% ; 2,51 \% ; 2,39 \% ; 2,32 \%$ dan $2,28 \%$. Hasil uji organoleptik menunjukkan bahwa penurunan kualitas kopi terjadi pada pemanasan di atas 45 menit. Berdasarkan data penelitian disimpulkan bahwa metode pemanasan dapat menurunkan kadar asam pada biji kopi dengan lama waktu pemanasan maksimal 45 menit untuk tetap menjaga kualitas cita rasa pada kopi.

Kata kunci: Coffea canephora, organoleptik, pemanasan, titrasi. 
LATAR BELAKANG

Kopi (Coffea sp.) merupakan salah satu komoditi hasil perkebunan yang banyak dikonsumsi sebagai minuman penyegar. (Zarwinda \& Sartika, 2018). Pada tahun 2016, produksi kopi di seluruh dunia mencapai 9,2 juta ton, sedangkan Indonesia mampu menghasilkan sekitar 689 ribu ton biji kopi. Berdasarkan data International Coffee Organization (ICO), tingkat konsumsi kopi di dunia pada tahun 2015 mencapai 152,2 juta bungkus yang terdiri dari $60 \mathrm{~kg}$ per bungkus dan mengalami peningkatan rata-rata tahunan 2\% sejak tahun 2011 (Handoyo, 2017).

Sentra produksi kopi Indonesia tersebar di beberapa provinsi dengan jumlah kontribusi produksi yang beragam, salah satunya adalah Sulawesi Selatan. Daerah Sulawesi Selatan memiliki letak geografis yang sangat baik bagi perkembangan dan peningkatan produksi tanaman kopi. Salah satu sentra produksi kopi yang terletak di wilayah dataran tinggi, yaitu desa Rantebua Kabupaten Toraja Utara (Supu, 2018).

Jenis kopi yang banyak dibudidayakan yaitu kopi robusta (Coffea canephora) dan arabika (Coffea arabica). Kopi robusta adalah jenis kopi yang paling banyak diproduksi di Indonesia yaitu mencapai $87,1 \%$ dari total produksi kopi di Indonesia (Hartatie \& Kholilullah, 2018). Walaupun kopi robusta merupakan varietas yang paling banyak dibudidayakan tetapi tidak mampu menguasai pasar global, hal ini disebabkan karena kopi robusta memiliki kandungan asam organik yang tinggi dan rasa yang lebih pahit daripada kopi arabika sehingga kurang disukai oleh konsumen lokal maupun internasioanal (Handoyo, 2017).

Komponen kimia di dalam kopi seperti kafein, asam klorogenat, trigonelin, karbohidrat, lemak, asam amino, asam organik dan mineral dapat menghasilkan efek yang menguntungkan dan juga sekaligus dapat membahayakan bagi kesehatan penikmat kopi. Golongan asam pada kopi akan mempengaruhi mutu dan memberikan aroma serta cita rasa yang khas. Jenis asam organik utama yang terkandung dalam biji kopi adalah asam oksalat, asam format, asam laktat, asam asetat dan asam sitrat (Towaha \& Rubiyo, 2016).

Nilai $\mathrm{pH}$ yang terdapat pada kopi terbentuk dari kandungan asam yang ada dalam kopi. Nilai pH biji kopi juga dipengaruhi oleh lokasi atau tempat tumbuh tanaman, besar kecilnya suhu pemanggangan, jenis pemanggang, dan metode pemasakan (Aditya et al., 2016). Nilai total asam memiliki korelasi terhadap nilai $\mathrm{pH}$ biji kopi. Semakin tinggi nilai total asam biji kopi, maka nilai $\mathrm{pH}$ akan semakin rendah. Pada perhitungan total asam pada kopi, asam yang digunakan sebagai acuan adalah asam sitrat karena asam ini banyak ditemui pada buah-buahan, terutama pada biji kopi.

Kopi robusta mengandung asam organik 0,5-3,5\%. Kandungan asam yang berlebih pada kopi dapat berdampak negatif terhadap kesehatan. Pada orang yang lambungnya sensitif terhadap asam, maka mengkonsumsi kopi dengan asam yang tinggi akan mengakibatkan produksi asam lambung naik (Farida et al., 2013). Jenis asam organik yang terdapat pada biji kopi adalah asam organik 
rantai karbon pendek yang dapat larut dalam air (Kuncoro et al., 2018), sebagian molekulnya akan terionisasi melepas atom hidrogen menjadi ion $\mathrm{H}^{+}$.

Kemampuan air dalam melarutkan asam pada kopi akan semakin meningkat dengan naiknya suhu sehingga pada penelitian ini dilakukan pada suhu air mendidih dengan variasi waktu, yang kemudian dianalisis dengan teknik titrasi untuk menentukan kadar asam pada biji kopi.

\section{METODE PENELITIAN}

\section{Bahan dan Peralatan}

Bahan yang digunakan pada penelitian ini adalah biji kopi robusta, indikator fenolftalein p.a, $\mathrm{NaOH}$ p.a (Merck), $\mathrm{H}_{2} \mathrm{C}_{2} \mathrm{O}_{4} \cdot 2 \mathrm{H}_{2} \mathrm{O}$ p.a (Merck), kertas saring biasa, akuades dan tissue.

Alat yang digunakan pada penelitian ini adalah kompor, panci, nyiru, huller, grinder, neraca analitik, sendok tanduk, batang pengaduk, labu semprot, spatula, corong, oven, klem, statif, pipet tetes, bulb dan alat gelas kimia lainnya yang umum digunakan di laboratorium.

\section{Prosedur Penelitian}

\section{Preparasi sampel}

Sampel buah kopi diambil dari petani kopi Desa Rantebua kemudian diolah dengan natural proses (pengolahan metode kering) dan full washing (pengolahan metode basah), kemudian masing-masing buah kopi dijemur hingga kering, kemudian dilakukan pengupasan kulit kopi menggunakan mesin huller. Kemudian biji kopi disortir untuk memisahkan buah kopi yang cacat dan berlubang hingga diperoleh biji kopi yang bersih.

\section{Penentuan kadar air pada kopi robusta (Fauzi et al., 2017)}

Sampel biji kopi sebanyak $5 \mathrm{~g}$ dimasukkan ke dalam botol timbang yang telah diketahui bobot kosongnya. Botol timbang yang berisi sampel dimasukkan dalam oven yang bersuhu $100-105{ }^{\circ} \mathrm{C}$ selama 16 jam, kemudian dimasukkan dalam eksikator selama 15 menit, lalu ditimbang hingga diperoleh berat konstan (selisih 0,0002 g).

\section{Penurunan kadar asam pada kopi (Wijaya \& Yuwono, 2015)}

Biji kopi yang telah disortir, ditimbang masing-masing $250 \mathrm{~g}$ sebanyak 6 bagian. Dimasukkan dalam panci lalu ditambahkan dengan air hingga seluruh biji kopi terendam, kemudian dipanaskan hingga mendidih dengan variasi lama perebusan masingmasing 15, 30, 45, 60, 75 dan 90 menit. Biji kopi hasil rebusan dibilas dengan air, kemudian ditiriskan dan dijemur hingga mencapai kadar air sekitar kurang dari 12,5\%.

\section{Penentuan kadar asam kopi}

Biji kopi digiling hingga ukuran 60 mesh. Sampel ditimbang $1 \mathrm{~g}$ dimasukkan ke dalam gelas kimia $100 \mathrm{~mL}$, kemudian diencerkan dengan $50 \mathrm{~mL}$ akuades. Sampel disaring dengan kertas saring biasa kemudian dibilas dengan akuades dan filtratnya dimasukkan dalam labu ukur $100 \mathrm{~mL}$ kemudian ditambahkan akuades hingga garis miniskus. Kemudian dipipet sebanyak $10 \mathrm{~mL}$ dan ditambahkan 2 tetes indikator fenolftalein 1\% $(\mathrm{b} / \mathrm{v})$, kemudian dititrasi dengan menggunakan larutan $\mathrm{NaOH} \quad 0,01 \quad \mathrm{~N}$ sampai terjadi perubahan warna menjadi merah muda. Asam 
tertitrasi dihitung sebagai kadar asam total dalam kopi.

\section{Uji organoleptik kopi}

Biji kopi disangrai dengan tipe roastingan dark (biji kopi berwarna hitam), kemudian biji kopi dihaluskan dengan menggunakan grinder hingga membentuk kopi bubuk. Kopi bubuk sebanyak $5 \mathrm{~g}$ dimasukkan dalam gelas uji, kemudian diseduh dengan $150 \mathrm{ml}$ air mendidih lalu dilakukan uji organoleptik terhadap warna, aroma dan rasa.

\section{HASIL DAN PEMBAHASAN}

\section{Hasil Analisis Kadar Air pada Biji Kopi Robusta}

Analisis kadar air pada biji kopi robusta dilakukan dengan pemanasan sampai bobot konstan dengan metode oven.

Tabel 1. Hasil analisis kadar air pada biji kopi robusta

\begin{tabular}{clc}
\hline No & Perlakuan Sampel & Kadar Air (\%) \\
\hline 1 & Pengolahan Kering & 10,02 \\
2 & Pengolahan Basah & 10,35 \\
3 & Pemanasan 15 Menit & 9,99 \\
4 & Pemanasan 30 Menit & 10,34 \\
5 & Pemanasan 45 Menit & 9,70 \\
6 & Pemanasan 60 Menit & 10,40 \\
7 & Pemanasan 75 Menit & 11,65 \\
8 & Pemanasan 90 Menit & 11,35 \\
\hline
\end{tabular}

Nilai kadar air terendah pada biji kopi dengan perlakuan pemanasan selama 45 menit, yaitu 9,70\% dan kadar air tertinggi pada biji kopi dengan perlakuan pemanasan selama 75 menit, yaitu 9,70\% (Tabel 1). Kadar air pada biji kopi sangat ditentukan oleh intesitas sinar matahari pada saat penjemuran biji kopi.

Pada penelitian ini untuk perlakuan pengolahan kering dibutuhkan waktu yang lebih lama yakni sekitar 2 minggu sedangkan pengolahan basah hanya dibutuhkan waktu sekitar 1 minggu untuk memperoleh biji kopi dengan kadar air kurang dari 12,5\%. Lama waktu pemanasan tidak berpengaruh secara langsung terhadap kadar air biji kopi karena sebelum disangrai biji kopi dijemur hingga kadar airnya kurang dari 12,5\% (Badan Standarisasi Nasional, 2008).

Data kadar air dari hasil penelitian ini menunjukkan perbedaan yang tidak terlalu signifikan, adapun penyebab perbedaan kadar air tersebut selain karena intensitas cahaya paada saat penjemuran, perbedaan kadar air pada kopi juga dipengaruhi oleh tempat menjemur kopi. Biji kopi yang dijemur pada nyiru (wadah anyaman bambu) akan lebih cepat mengering dibandingkan dengan biji kopi yang dijemur pada wadah yang terbuat dari porselin seperti baki, hal ini disebabkan karena pada wadah nyiru terdapat lubanglubang kecil yang sangat baik sebagai tempat terbuangnya air.

\section{Hasil Analisis Kadar Asam pada Biji Kopi Robusta \\ Analisis kadar asam pada biji kopi} robusta dilakukan dengan teknik titrasi dengan menggunakan larutan standar $\mathrm{NaOH}$ yang telah distandarisasi dengan larutan asam oksalat. Reaksi yang terjadi adalah sebagai berikut:

$$
\begin{aligned}
\mathrm{H}_{2} \mathrm{C}_{2} \mathrm{O}_{4} .2 \mathrm{H}_{2} \mathrm{O}+2 \mathrm{NaOH} & \rightarrow \mathrm{Na}_{2} \mathrm{C}_{2} \mathrm{O}_{4}+4 \mathrm{H}_{2} \mathrm{O} \\
\mathrm{C}_{6} \mathrm{H}_{8} \mathrm{O}_{7}+3 \mathrm{NaOH} & \rightarrow \mathrm{Na}_{3} \mathrm{C}_{6} \mathrm{H}_{5} \mathrm{O}_{7}+3 \mathrm{H}_{2} \mathrm{O}
\end{aligned}
$$

Data hasil penentuan kadar asam kopi robusta dengan beberapa perlakuan pada Tabel 2 menunjukkan bahwa kadar asam tertinggi adalah pada pengolahan kering yaitu 3,65\%, sedangkan kadar asam pada pengolahan basah lebih rendah yaitu $3,42 \%$. 
Tabel 2. Hasil analisis kadar asam pada biji kopi robusta.

\begin{tabular}{llcc}
\hline No & Perlakuan Sampel & $\begin{array}{c}\text { Kadar } \\
\text { Asam } \\
(\%)\end{array}$ & $\begin{array}{c}\text { Penurun- } \\
\text { an Kadar } \\
\text { Asam } \\
(\%)\end{array}$ \\
\hline 1 & Pengolahan Kering & 3,65 & - \\
2 & Pengolahan Basah & 3,42 & 0,23 \\
3 & Pemanasan 15 Menit & 3,03 & 0,62 \\
4 & Pemanasan 30 Menit & 2,76 & 0,89 \\
5 & Pemanasan 45 Menit & 2,51 & 1,14 \\
6 & Pemanasan 60 Menit & 2,39 & 1,26 \\
7 & Pemanasan 75 Menit & 2,32 & 1,33 \\
8 & Pemanasan 90 Menit & 2,28 & 1,37 \\
\hline
\end{tabular}

Perbedaan kadar asam pada kedua jenis pengolahan kopi yang dilakukan terjadi karena pada pengolahan basah, kopi diolah dengan menggunakan air untuk mencuci lendir pada kulit buah kopi. Pada pengolahan kering, kopi langsung dijemur setelah dipetik sehingga asam organik yang terkandung pada kulit kopi dapat melengket dan terserap pada biji kopi sehingga memiliki kadar asam yang lebih tinggi.

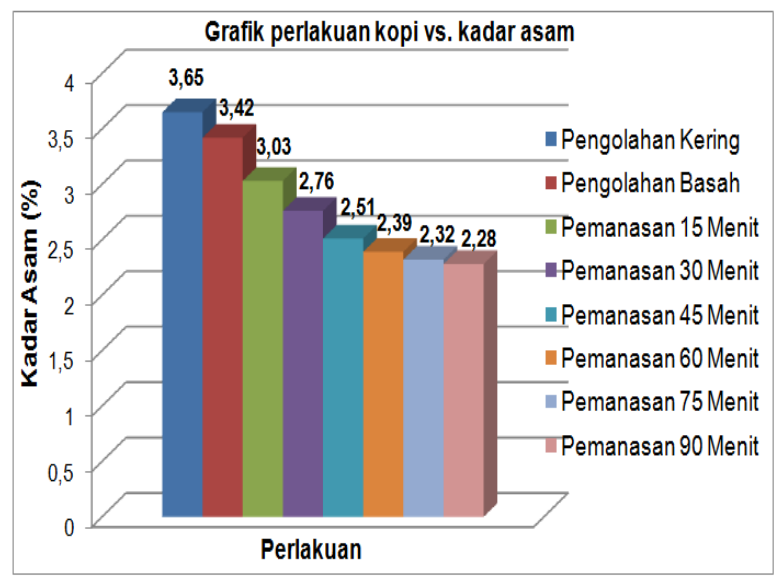

Gambar 1. Profil histogram penurunan kadar asam kopi robusta

Data hasil penelitian, menunjukkan bahwa kadar asam pada biji kopi robusta terus menurun seiring dengan semakin lamanya waktu pemanasan (Gambar 1). Total asam tertitrasi kopi robusta dengan beberapa perlakuan, yaitu 2,28-3,65\%. Data tersebut sesuai dengan pernyataan Yusianto (1999) bahwa kadar asam tertitrasi pada kopi robusta yaitu sekitar 1,7-3,5\%. Hasil penelitian ini membuktikan bahwa pemanasan dapat menurunkan kadar asam pada biji kopi secara signifikan, namun dari Gambar 1 terlihat bahwa pada pemanasan 60 menit, penurunan asam kopi mulai stabil, dan uji organoleptik menunjukkan bahwa pada pada pemanasan 45 menit, kualitas aroma dan rasa kopi mulai menurun.

Penurunan asam pada kopi robusta dengan teknik pemanasan dapat dilakukan dengan tetap menjaga kualitas cita rasa pada kopi sebaiknya dilakukan pada waktu pemanasan maksimal 45 menit dengan penurunan asam sebesar $1,14 \%$.

\section{Hasil Uji Organoleptik Kopi Robusta}

Mutu kopi sangat bergantung pada tinjauan organoleptik. Berdasarkan syarat dari Badan Standarisasi Nasional (2004), kopi bubuk harus memenuhi syarat dengan nilai normal untuk tinjauan organoleptik warna, aroma dan rasa. Penelitian ini dilakukan dengan jumlah panelis 10 orang, setiap panelis memberikan penilaian terhadap warna, aroma dan rasa.

Dari hasil uji organoleptik yang dikonversi ke dalam persen, menunjukkan bahwa warna kopi untuk semua perlakuan adalah hitam normal (Tabel 3), Hasil ini sesuai dengan syarat SNI 01-3542-2004 bahwa persyaratan mutu warna kopi bubuk adalah hitam normal. 
Tabel 3. Data hasil uji organoleptik warna kopi robusta

\begin{tabular}{lllcccc}
\hline \multirow{2}{*}{ No } & \multirow{2}{*}{ Perlakuan Sampel } & \multicolumn{5}{c}{ Hasil Uji Warna (\%) } \\
\cline { 3 - 7 } & & 1 & 2 & 3 & 4 & 5 \\
\hline 1 & Pengolahan Kering & - & 30 & 70 & - & - \\
2 & Pengolahan Basah & - & 20 & 80 & - & - \\
3 & Pemanasan 15 Menit & - & 10 & 90 & - & - \\
4 & Pemanasan 30 Menit & - & 10 & 90 & - & - \\
5 & Pemanasan 45 Menit & - & - & 100 & - & - \\
6 & Pemanasan 60 Menit & - & 10 & 90 & - & - \\
7 & Pemanasan 75 Menit & - & - & 100 & - & - \\
8 & Pemanasan 90 Menit & - & - & 100 & - & - \\
\hline
\end{tabular}

Keterangan: 1. Sangat Hitam, 2. Agak Hitam, 3. Hitam Normal, 4. Agak Kurang Hitam, 5. Sangat Kurang Hitam

Data hasil penelitian pada Tabel 3 menunjukkan bahwa proses pemanasan untuk menurunkan kadar asam pada biji kopi tidak berpengaruh secara langsung terhadap warna kopi (Badan Standarisasi Nasional, 2004).

Tabel 4. Data hasil uji organoleptik aroma kopi robusta

\begin{tabular}{clccccc}
\hline \multirow{2}{*}{ No } & \multirow{2}{*}{ Perlakuan Sampel } & \multicolumn{6}{c}{ Hasil Uji Aroma (\%) } \\
\cline { 3 - 7 } & & 1 & 2 & 3 & 4 & 5 \\
\hline 1 & Pengolahan Kering & - & 70 & 30 & - & - \\
2 & Pengolahan Basah & - & 80 & 20 & - & - \\
3 & Pemanasan 15 Menit & - & 60 & 40 & - & - \\
4 & Pemanasan 30 Menit & - & 30 & 70 & - & - \\
5 & Pemanasan 45 Menit & - & 20 & 40 & 40 & - \\
6 & Pemanasan 60 Menit & 10 & - & 50 & 40 & - \\
7 & Pemanasan 75 Menit & - & - & 40 & 50 & 10 \\
8 & Pemanasan 90 Menit & - & - & 30 & 60 & 10 \\
\hline
\end{tabular}

Keterangan: 1. Sangat Tajam, 2. Agak Tajam, 3. Aroma Normal, 4. Agak Kurang Tajam, 5. Sangat Kurang Tajam

Uji aroma pada kopi robusta menunjukkan bahwa aroma kopi untuk pengolahan kering, pengolahan basah dan pemanasan 15 menit adalah agak tajam, aroma kopi pada pemanasan 30 menit adalah normal, sedangkan pada pemanasan mulai dari 45 menit dan seterusnya menyebabkan kopi mengalami penurunan aroma (Tabel 4).
Berdasarkan SNI 01-3542-2004 bahwa persyaratan mutu aroma kopi bubuk adalah aroma normal dan tidak tercium aroma asing. Data hasil penelitian tersebut menunjukkan bahwa waktu pemanasan untuk menurunkan kadar asam pada biji kopi dengan tetap menjaga kualitas aroma pada kopi adalah maksimal 45 menit (Badan Standarisasi Nasional, 2004).

Tabel 5. Data hasil uji organoleptik rasa kopi robusta

\begin{tabular}{|c|c|c|c|c|c|c|}
\hline \multirow{2}{*}{ No } & \multirow{2}{*}{ erlakuan Sampel } & \multicolumn{5}{|c|}{ Hasil Uji Warna (\%) } \\
\hline & & 1 & 2 & 3 & 4 & 5 \\
\hline 1 & & - & 70 & 20 & 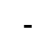 & - \\
\hline 2 & Pengolahe & - & 70 & 20 & - & 10 \\
\hline 3 & 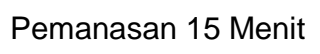 & - & 30 & 60 & 列 & 10 \\
\hline 4 & Pemanasan 30 Menit & - & 20 & 70 & 10 & - \\
\hline 5 & Pema & - & 10 & 70 & 20 & - \\
\hline 6 & 60 Menit & 10 & - & 30 & 60 & - \\
\hline 7 & Pemanasan 75 Menit & - & - & 20 & 70 & 10 \\
\hline 8 & Pemanasan 90 Menit & - & - & 20 & 70 & 10 \\
\hline \multicolumn{7}{|c|}{$\begin{array}{c}\text { Keterangan: 1. Sangat Pahit, 2. Agak Pahit, 3. Pahit } \\
\text { Normal, 4. Agak Kurang Pahit, } 5 . \\
\text { Sangat Kurang Pahit }\end{array}$} \\
\hline & Rasa kopi robust & & & הות & & \\
\hline
\end{tabular}

kering, pengolahan basah, pada pemanasan 15; 30 dan 45 menit adalah pahit normal, sedangkan kopi pada pemanasan 60,75 dan 90 menit menyebabkan kopi mengalami penurunan kualitas rasa (Tabel 5). Berdasarkan SNI 01-3542-2004 bahwa persyaratan mutu rasa kopi bubuk adalah rasa normal dan tidak ada rasa asing pada kopi. Data hasil penelitian tersebut menunjukkan bahwa waktu pemanasan untuk menurunkan kadar asam pada biji kopi dengan tetap menjaga kualitas rasa pada kopi adalah maksimal 45 menit (Badan Standarisasi Nasional, 2004). 


\section{KESIMPULAN}

Hasil analisis kadar air pada biji kopi robusta (Coffea canephora) untuk perlakuan pengolahan kering sebesar 10,02\%, pengolahan basah sebesar $10,35 \%$ dan pada pemanasan selama 15, 30, 45, 60, 75 dan 90 menit berturut-turut sebesar 9,99\%; 10,34\%; $9,70 \% ; 10,40 \% ; 11,65 \%$ dan $11,36 \%$. Hasil analisis kadar asam untuk perlakuan pengolahan kering sebesar 3,65\%, pengolahan basah sebesar $3,42 \%$, dan pada pemanasan selama 15, 30, 45, 60, 75 dan 90 menit berturut-turut sebesar $3,03 \% ; 2,76 \%$; $2,51 \% ; 2,39 \% ; 2,32 \%$ dan 2,28\%. Hasil uji organoleptik menunjukkan bahwa penurunan kualitas kopi terjadi pada pemanasan di atas 45 menit dengan penurunan kadar asam sebesar $1,14 \%$. Berdasarkan data penelitian disimpulkan bahwa metode pemanasan pada suhu air mendidih dapat menurunkan kadar asam pada biji kopi dengan lama waktu pemanasan maksimal 45 menit untuk tetap menjaga kualitas cita rasa pada kopi

\section{DAFTAR PUSTAKA}

Aditya, I. W., Nocianitri, K. A., \& Yusasrini, N. L. A. (2016). Kajian Kandungan Kafein Kopi Bubuk, Nilai pH dan Karakteristik Aroma dan Rasa Seduhan Kopi Jantan (Pea berry coffee) dan Betina (Flat beans coffee) Jenis Arabika dan Robusta. Jurnal IImu Dan Teknologi Pangan (ITEPA), 5(1). https://ojs.unud.ac.id/index.php/itepa/arti cle/view/22653

Badan Standarisasi Nasional. (2004). Standar Nasional Indonesia 01-3542-2004: Kopi Bubuk. BSN, Jakarta.

Badan Standarisasi Nasional. (2008). Standar Nasional Indonesia 01-2907-2008: Biji Kopi. BSN, Jakarta.
Farida, A., R, E. R., \& Kumoro, A. C. (2013). Penurunan Kadar Kafein dan Asam Total Pada Biji Kopi Robusta Menggunakan Teknologi Fermentasi Anaerob Fakultatif Dengan Mikroba Nopkor MZ-15. JURNAL TEKNOLOGI KIMIA DAN INDUSTRI, 2(2): 70-75.

Fauzi, M., Choiron, M., \& Astutik, Y. D. P. (2017). Karakteristik Kimia Kopi Luwak Robusta Artifisial Terfermentasi Oleh Ragi Luwak dan a-Amilase. Jurnal Penelitian Pascapanen Pertanian, 14(3): 144-153. https://doi.org/10.21082/jpasca.v14n3.2 017.144-153

Handoyo, F. (2017). Ekstraksi dan Karakterisasi Green Coffee Extract (GCE) dari Kopi Robusta. Institut Pertanian Bogor, Bogor.

Hartatie, D., \& Kholilullah, A. (2018). Uji Tingkat Kesukaan Konsumen Pada Seduhan Kopi Robusta (Coffea canephora) Plus Madu. Implementasi IPTEK dalam Mewujudkan Ketahanan Pangan Nasional. Implementasi IPTEK dalam Mewujudkan Ketahanan Pangan Nasional, 25 November 2018. Jember, Jawa Timur, Indonesia. https://doi.org/10.25047/agropross.2018 .93

Kuncoro, S., Sutiarso, L., Karyadi, J. N. W., \& Masithoh, R. E. (2018). Kinetika Reaksi Penurunan Kafein dan Asam Klorogenat Biji Kopi Robusta melalui Pengukusan Sistem Tertutup. Agritech, 38(1): 105. https://doi.org/10.22146/agritech.26469

Supu, A. (2018). Karakterisasi Mutu Fisik Kimia dan Citarasa Kopi yang Potensial Dikategorikan sebagai Kopi Spesialti. Balai Besar Industri Hasil Perkebunan, Makassar.

Towaha, J., \& Rubiyo, R. (2016). Physical Quality and Flavor of Arabica Coffee Beans Fermented by Probiotic Microbes from Civet Digestive System. Jurnal Tanaman Industri dan Penyegar, 3(2): 61-70. https://doi.org/10.21082/jtidp.v3n2.2016. p61-70 
Wijaya, D. A., \& Yuwono, S. S. (2015). Pengaruh Lama Pengukusan Dan Konsentrasi Etil Asetat Terhadap Karakteristik Kopi pada Proses Dekafeinasi Kopi Robusta. Jurnal Pangan Dan Agroindustri, 3(4).. https://jpa.ub.ac.id/index.php/jpa/article/ view/280

Yusianto. (1999). Komposisi Kimia Biji Kopi dan Pengaruhnya Terhadap Cita Rasa Seduhan. Warta Pusat Penelitian Kopi Dan Kakao, 15: 190-202.

Zarwinda, I., \& Sartika, D. (2018). Pengaruh Suhu Dan Waktu Ekstraksi Terhadap Kafein dalam Kopi. Lantanida Journal, 6(2): $\quad$ 180-191. https://doi.org/10.22373/lj.v6i2.3811 